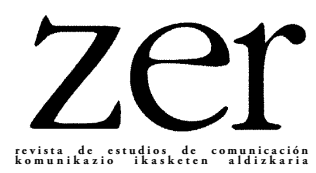

\title{
Communication and effectiveness of the protest: Anti-fracking movements in Spain
}

\author{
Protestaren eraginkortasuna eta komunikazioa: \\ frackingaren aurkako mugimenduak Espainian ${ }^{1}$ \\ Comunicación y eficacia de la protesta: \\ los movimientos antifracking en España ${ }^{2}$ \\ José María Herranz de la Casa \\ Universidad Castilla-La Mancha \\ Àngels Álvarez-Villa, María Teresa Mercado-Sáez \\ Universidad CEU Cardenal Herrera, CEU Universities
}

\begin{abstract}
RESUMEN: Este trabajo analiza la eficacia de las estrategias de comunicación de los movimientos antifracking en España. El estudio plantea la eficacia de las reivindicaciones que realizan tanto ONGs como plataformas ciudadanas en estos últimos años en función de la respuesta y el compromiso de la administración pública. En España, las protestas antifracking son protagonizadas por las ONG ambientalistas y los movimientos sociales ligados al territorio en forma de plataformas o asambleas contrarias al fracking. El poder de las plataformas ciudadanas ha logrado que los gobiernos regionales apoyen sus reivindicaciones frente al gobierno central, con la competencia estatal.
\end{abstract}

PALABRAS CLAVE: Medio Ambiente, Comunicación política, Ciudadanía, Movimientos Sociales, Redes Sociales.

1 Lan hau Ekonomia eta Lehiakortasuneko Ministerioaren Plan Nazionalaren ikerketa proiektu baten ondoriozkoa da: Análisis del tratamiento informativo de las políticas energéticas en España, procesos de recepción y participación de organizaciones sociales (erreferentzia: CSO2012-38363).

${ }^{2}$ Este trabajo procede de un proyecto de investigación del Plan Nacional de Ministerio de Economía y Competitividad titulado «Análisis del tratamiento informativo de las políticas energéticas en España, procesos de recepción y participación de organizaciones sociales» (referencia CSO2012-38363). 
LABURPENA: Lan honetan, Espainiako frackingaren aurkako mugimenduen komunikazio estrategien eraginkortasuna aztertzen da. Azterlanak azken urteotan bai GKEek bai herritarren plataformek eginiko aldarrikapenen eraginkortasuna planteatzen $d u$, administrazio publikoaren erantzunaren eta konpromisoaren arabera. Espainian, frackingaren aurkako protestak ingurumenaren aldeko GKEek eta frackingaren aurkako plataforma edo asanblada forma duten lurraldeari lotutako gizarte mugimenduek burutzen dituzte. Herritarren plataformen indarrak ahalbidetu $d u$ erregio gobernuek horien aldarrikapenak babestea gobernu zentralaren aurrean, estatuko aginpidearekin.

HITZ-GAKOAK: Ingurumena; komunikazio politikoa; herritarrak; gizarte mugimenduak, sare sozialak.

ABSTRACT: This paper analyzes the protest and communication strategies by anti-fracking movements in Spain. This study explores the effectiveness of demands from Non-Governmental Organizations (NGOs) and citizen platforms in the past few years in terms of governmental legislative agreements or decisions. In Spain, the anti-fracking protests are led by environmental NGOs and local social movements in the form of platforms or grassroots assemblies against fracking. The power of citizen platforms, spread throughout Spain, have managed to get regional governments to support their demands after the central government.

KEYWORDS: Environment, Political communication, Citizenship, Social movements, Social media.

^ Correspondencia a: José María Herranz de la Casa. Fac. de periodismo Universidad de Castilla-La Mancha Campus de Cuenca. Dirección: Aulario Polivalente, Campus Universitario,s/n (16071 Cuenca).josemaria.herranz@uclm.es

http://orcid.org/0000-0002-3667-2664

Cómo citar: Herranz de la Casa, José María; Álvarez-Villa, Àngels; Mercado-Sáez, María Teresa. 2018. Communication and effectiveness of the protest: Anti-fracking movements in Spain. Zer. 23(45). 35-56.

https://doi.org/10.1387/zer.19543

Recibido: 5 abril 2018; aceptado: 15 octubre 2018

1137-1102 y 1989-631X / C 2018 UPV/EHU

(c) (i) Esta obra está bajo una licencia Creative Commons Atribución 4.0 Internacional 


\section{Introduction}

In the year 2011, Time Magazine granted its Person of the Year title to «The Protester», in reference to each one of the citizens that participated in the citizen movements that shook the world that year, the Arab Spring, Spain's 15M movement and Occupy Wall Street. These protests were the prelude to new «movement of the squares» (Gerbaudo, 2012) throughout the entire world. In Spain, the economic crisis and the unease in relation to the public policies of the governors increased the levels of participation and social response through social movements. The Spain's 15M movement was followed by the white and green waves, platforms for the defense of public education and health, or the Anti-eviction platform (PAH), and ended up crystallizing in the political party Podemos, or in political candidacies such as that of Ada Colau, current mayor of Barcelona and previously an activist with PAH (Anduiza, Cristancho \& Sabucedo, 2014; Monterde, Calleja-Lopez, Aguilera, Barandiaran \& Postill, 2015).

In the environmental scope, the anti-fracking movements have intensified their work from 2013 to 2016 (Mercado, Álvarez \& Herranz, 2014), though this protest had been active in the United States since the year 2003 (Batill \& FeldpauschParker, 2013). This study focuses on the communication strategies and the effectiveness of the anti-fracking movement protests in Spain, a technique also known as hydraulic fracturing, which consists of extracting gas from underground with the help of pressurized water and chemical substances. Its negative effects on the environment generate steep controversy, and the anti-fracking movement aims to demonstrate these effects against the support of the Spanish government, which seeks lower energy dependency.

Nearly fifty city councils from the region of Cantabria and Castilla León (all of them integrated in the Spanish Federation of Municipalities and Provinces, FEMP) sent a letter to Jose Manuel Soria, Minister of Industry, in January 2013. In this letter, the city councils showed their worries about the negative impact of fracking in local environment and in the health of their residents. One month later, Jose Manuel Soria answered that: «Ministry considers that fracking technic should be admitted» whenever it is safety for environment and residents. And also added that all the corporations should hire a liability insurance policy «for facing some eventual incident». ${ }^{3}$

The research questions are:

- Q1: What kinds of communication strategies do anti-fracking movement develop in Spain?

- Q2: Are these strategies effectiveness to forbid fracking in Spain?

\footnotetext{
${ }^{3}$ https://elpais.com/sociedad/2013/03/16/actualidad/1363471123_789066.html
} 
The objectives of this research are, firstly to show a map of the strategies of the anti-fracking movements and the environmental NGOs between 2012 and 2015 in Spain, most of them using digital tools as blogs, web, social media or media. Secondly, we will try to evaluate the effectiveness of protest in terms of governmental legislative agreements or decisions.

\section{Overview}

\subsection{Participation in the public SPhere of Social organizations: FROM NGOS TO SOCIAL MOVEMENTS}

The first concept that must be clarified is the difference between social movements and organizations that frame the entire context of the anti-fracking protest. Among the authors that have established the set of sub-groups that form part of the social organizations, we can highlight Jerez and Revilla (1997: 30-31) who differentiate between social movements, civil associationism, non-governmental organizations (NGO), community networks and foundations. Basically, the NGOs tend to be more general in their objectives, their duration over time is unlimited and they have a higher degree of institutionalization in comparison to the sporadic movements related to the problems addressed and with a more unstructured operation (Velázquez, 2005: 40-41).

All of these social organizations, a term which we will use to integrate NGOs and social movements, include citizen participation in public life and represent one way of overcoming the administrative and political deficits (Brugé, Font \& Gomà, 2003).

Transparency and trust continue to support the work of the NGOs in recent years (CIS, 2011: Edelman, 2015) in comparison to other institutions, while the social movements are consolidated through the strength of the protest. In the environmental scope, the protest intensifies in the decade of the 90's and is notable for its development in the local context (Jiménez, 2005: 107-109). The Prestige oil spill disaster in 2002 was a turning point in citizen solidarity and for concern for the environment. This growing activism has been consolidated in recent years through citizen social movements, embedded in the local space and leading to the anti-fracking platforms, the platforms against oil prospecting in the Canary and Balearic Islands or the platform against the Centralized Temporary Storage (CTS) of nuclear waste.

\subsection{The COMMUNiCATION FUNCTION OF SOCIAL ORGANIZATIONS}

For social organizations, communication management has a triple dimension: raising awareness among citizens, generating notoriety in the press and generating spaces for 
meetings and debate with the objective of having an influence on the public sphere. The consequences of these actions may improve the capacity to educate and create a more participative culture among citizens that could generate commitment to and participation with their surroundings, leading to the development of communication for social change (Nos, Iranzo \& Farné, 2012).

Communication is understood as a strategy and an instrument, and as a global process for relating to and understanding the other party. This process implies dialogue, exchange, meeting points, spaces for debate, participation and further education, as stated by Erro (2002: 25), "all communication processes, by nature, are educational». However, the key is in knowing whether the communication, in these cases, is orientated towards selling the organization of the society, or whether it is truly orientated towards social change, energizing social processes of change and promoting citizen participation, as highlighted by Victor Marí (Ramil, 2012: 12).

In this communication process, the relationship between social organizations and the press is presumed to be relevant. To achieve that the problems that concern citizens become part of the informative agenda and the public agenda, as well as the governmental and electoral agenda is a challenge. Entry to the informative agenda for the social organizations implies becoming an expert source of information, although this is sometimes at the cost of sensationalizing their actions.

Another relevant point, when discussing communication, is the use of "social media" by the social organizations. There are already various research studies that identify their potential in social organizations in order to achieve more participative communication with the citizens, as a cyber-activism tools and to improve "engagement» with the entire public (Waters, Burnett, Lamm \& Lucas, 2009; Briones, Kuch, Liu \& Jin, 2011; Lovejoy \& Saxton, 2012; Nah \& Saxton, 2013; Guo \& Saxton, 2013; Arroyo, Baladrón \& Martín, 2013; Gabalín, 2014; Iranzo \& Farné, 2014; Toret, J., Calleja, A. et al., 2015), and also about which paths should be followed and reflected upon in order to achieve social change (Della Porta, 2011; Ramil, 2012). However, there are authors such as Buckingham and Rodríguez (2013) that state that the new information technologies are not free and democratic spaces, because on many occasions they reproduce traditional situations of domination and control within the network. There are also other studies that question the effectiveness of the use of social media (Bortree \& Seltzer, 2009; Greenberg \& MacAulay, 2009). As Gerbaudo (2012: 13) explain:

I argue that far from inaugurating a situation of absolute 'leaderlessness', social media have in fact facilitated the rise of complex and 'liquid' (Bauman, 2000) or 'soft' forms of leadership which exploit the interactive and participatory character of the new communication technologies. 
Also Castells (2015: 249) describes the profit of social media in the action of social movements:

Los movimientos sociales en red de nuestra época se basan en gran medida en Internet, un elemento necesario aunque no suficiente de su acción colectiva. Las redes sociales digitales basadas en Internet y en plataformas inalámbricas son herramientas decisivas para movilizar, organizar, deliberar, coordinar y decidir.

Althought some aspects of social media have also negatively impacted citizenship, some author as García, Fernández y Del Olmo (2018: 160):

Conceptos como el de clickactivismo o slacktivism («activismo de sofá») han surgido de la mano de las redes sociales, y hacen sentir en sus usuarios que son ciudadanos activos ante situaciones sociales que demandan su participación.

Tascón and Quintana (2012: 90-91) point out how the Internet and social media play a fundamental role in the protest of social movements, but this is compounded by the symbols that create meanings as well, and at this point the environmental movements are an example: «El Rainbow Warrior, ahora, navega en las redes sociales» in a reference to Greenpeace ship. So for this reason it is not only fundamental the social media but also the "protest camps, assemblies, demonstrations, sit-ins and popular marches on the ground: multiple variations of a politics of the streets performed 'shoulder to shoulder' rather than 'peer to peer'» (Gerbaudo, 2012: 160).

\subsection{IMPLICATIONS AND EFFECTIVENESS OF THE PROTEST}

Each day is more important in the role of social organizations as relevant actors on a global scale, and thus it is stated by some research studies when evaluating the strategic use of communication and its impact on the surroundings (Seo, H., Kim, J.Y. \& Yang, S.U. 2009; Schwarz \& Fritsch, 2014; Herranz, 2014).

According to the report by Burson Marsteller (2013), the non-governmental organizations are the second most effective in their pressure and lobbying activities (46\%) in the scope of the European Union, after the business associations (51\%), particularly in the field of the environment. As Gomis (2000) explains, social organizations do not hold any of the three powers (legislative, executive, judicial); however, their political participation pertains to the field of public opinion. The pressure and influence upon citizens allows them to hold, to a greater or lesser extent, power that is relatively small, but real. Nye (2004) calls this a «soft power», or power of conviction, against the hard coercive power of the public administrations or compa- 
nies, which on occasion allows us to talk about the growing capacity of political influence. And in the environmental area, lobby is very relevant (Herranz, Sidorenko y Cantero, 2017).

The strategies of implications and activism can be very varied in order to have an effect on companies and public administrations. Berry (1977) identifies four advocacy strategies: litigation, confrontation, information and pressure. The combination of formal-direct (institutionalized) strategies and actions with informal-indirect (mobilizing) strategies and actions allows for control, implications and the mobilizing and informing capacity. These strategies and actions range from institutional participation in committees, councils, forums or summits and legal claims and lawsuits to cyber-actions, demonstrations or the presentation of reports (Herranz, 2011: 108).

\section{TABLE 1}

Strategies and actions for control, implication, mobilization and raising awareness depending on the target

\begin{tabular}{|c|c|c|}
\hline Target & Strategies & Actions \\
\hline \multirow{4}{*}{$\begin{array}{l}\text { Public } \\
\text { Administration } \\
\text { (implications } \\
\text { and control) }\end{array}$} & $\begin{array}{l}\text { Institutional } \\
\text { Participation }\end{array}$ & $\begin{array}{l}\text { Participation in commissions, committees, advisory councils, ob- } \\
\text { servatories, forums, etc. }\end{array}$ \\
\hline & $\begin{array}{l}\text { Presentation } \\
\text { of institutional } \\
\text { documents }\end{array}$ & $\begin{array}{l}\text { Participation in the creation of work documents. Green papers, } \\
\text { white papers and presentation of legislative initiatives, resolu- } \\
\text { tions, defense of motions, etc. }\end{array}$ \\
\hline & $\begin{array}{l}\text { Encounters and } \\
\text { meetings }\end{array}$ & $\begin{array}{l}\text { Formal and informal meetings, organized visits for public author- } \\
\text { ities, seminars, forums and summits }\end{array}$ \\
\hline & $\begin{array}{l}\text { Judicial actions } \\
\text { and allegations }\end{array}$ & $\begin{array}{l}\text { Judicial participation (lawsuits), complaints (police, courthouse) } \\
\text { and allegations (legislative projects, management schemes, li- } \\
\text { censes) }\end{array}$ \\
\hline \multirow{5}{*}{$\begin{array}{l}\text { Citizens } \\
\text { (mobilization) }\end{array}$} & Public requests & Letters, documents, signatures collected, requests \\
\hline & $\begin{array}{l}\text { Generation of } \\
\text { information } \\
\text { and opinion }\end{array}$ & $\begin{array}{l}\text { Websites in favor or against (anti-sites) a certain cause, blogs, dis- } \\
\text { cussion groups, social networks, mass e-mails, surveys, studies, } \\
\text { reports }\end{array}$ \\
\hline & $\begin{array}{l}\text { Organization of } \\
\text { events }\end{array}$ & $\begin{array}{l}\text { Events, special events, encounters, seminars, congresses, summits, } \\
\text { exhibitions, fairs }\end{array}$ \\
\hline & $\begin{array}{l}\text { Protest } \\
\text { concentrations }\end{array}$ & Concentrations, demonstrations, strikes, protests, escraches \\
\hline & $\begin{array}{l}\text { Actions of } \\
\text { confrontation }\end{array}$ & $\begin{array}{l}\text { Aggressions, damage to property, theft, occupation, blockage, ac- } \\
\text { cess cuts, information hacking }\end{array}$ \\
\hline $\begin{array}{c}\text { Media } \\
\text { (awareness) }\end{array}$ & $\begin{array}{l}\text { Public } \\
\text { presentations }\end{array}$ & Press conferences, informative acts, studies, reports \\
\hline
\end{tabular}

Source: Own creation based on Herranz (2011: 108). 
In the political scope, it is difficult to talk about the effectiveness of the impact of actions with political implications, although it can be measured based on the response and commitment of the public administration. Following the categories of the International Institute for Environment and Development (IIED) (Beloe, 2005), the response can be: support, oral or written without a binding nature; collaboration, initiating consultation actions; help, assisting with training resources and launch of measures; or mandate, putting legal and regulatory criteria into practice (governmental legislative agreements or decisions). However, the opposite can also occur, where the response to the demands by the social organizations is null and therefore, a 0 category would have to be added, which could be called: Omission, which may cause the mobilizations to be emphasized. For example, in the debate and conflict over fracking in Spain, the levels of impact depend on the local, autonomic or national government (Mercado, Álvarez \& Herranz, 2014).

We can speak of a substantive impact, measured quantitatively (number of meetings, reports, press appearances) or qualitatively (commitments, alliances, visibility, establishment of agendas, objectives); and we can also speak of a cultural or symbolic impact, understood as the capacity to inform the public opinion, to raise awareness and to modify the opinion climate, and to thus be able to bring about change. Nos, Iranzo \& Farné (2012) discuss the concept of cultural effectiveness of communication in order to explain the capacity to influence public opinion. However, as explained by Castells (2009), these changes may require a lot of time. More than four decades of efforts from the ecologist movements were necessary to alert citizens to climate change, and to have an effect on the recent political decisions made in this sense.

The recent events in Spain make us wonder whether the true effectiveness for these implications is more related to the support of ideologies represented by different political parties, which have the capacity to change the legislation: see the closure of Garoña for 2013 and the re-opening after the change in national government in 2011 or the veto of the Centralized Temporary Storage (CTS) after the change in government Castile-La Mancha in the last autonomic elections of May 2015. All of these are grievances of the platforms that they have been working on for many years, and with the change of regional or national governments they see their demands either fulfilled or frustrated.

Despite these situations, we can also talk about the success or effectiveness of the citizen social movements. For example, the halting of the political-corporate initiative of the Balboa refinery in the province of Badajoz, which in 2012 received a negative Environmental Impact Statement (EIS), where one of the reasons stated in the conclusions of the resolution was the enormous social opposition to the project that was led since 2005 by the citizen platform Refinería No [Refinery No] (Torrella, 2014). 


\section{Case study: Anti-fracking organizations and platforms in Spain}

\subsection{METHOD}

In this research, content analysis methodology is used to review the communication strategies of anti-fracking movements in Spain. And the categorization variables are based on Herranz (2011: 107). In the table 2 appears when they used (1) or not (0) the different strategies aimed to:

- Public Administration (implications and control): Institutional Participation, Presentation of institutional documents, Encounters and meetings, judicial actions and allegations.

- Citizens (mobilization): Public requests, Generation of information and opinion, Organization of events, Protest concentrations, Actions of confrontation.

- Media (awareness, visibility): Press conferences, informative acts, studies and reports.

The sample covers web pages and press news where appears the communication strategies of five national environmental NGOs in Spain and five anti-fracking movements that were born in regional counties after a corporation requested or obtained a unconventional hydrocarbon exploration permissions. In press, the words used in the database MyNews were «fracking» and "hydraulic fracturing». In addition to Europa Press agency, the newspapers used were the most read Spain newspapers (El País and El Mundo) in their digital version and the regional newspapers: El Diario Montañés (Cantabria), Noticias de Álava, El Correo (País Vasco, Burgos); Diario de Sevilla, Sur de Málaga, Diario de Cádiz, Diario Jaén (Andalucía); Mediterráneo de Castellón (Comunidad Valencia); and Diario de León (Castilla-León).

The five NGOs are Greenpeace, WWF-Spain, Ecologists in Action, Friends of the Earth and SEO/Birdlife, the main environmental organizations with national presence that are recognized as «the five environmental NGOs» themselves, ${ }^{4}$ all of which have websites and presence on social media (Facebook, Twitter and Insta-

\footnotetext{
${ }^{4}$ http://archivo-es.greenpeace.org/espana/es/news/2014/Octubre/cinco-ong-ecologistas-contraprospecciones-repsol-canarias/

https://www.iagua.es/noticias/espana/seobirdlife/15/05/29/cinco-principales-ong-ambientalesproponen-4-prioridades-nuevos

https://www.lamarea.com/2014/02/24/las-cinco-grandes-ong-ambientales-presentan-14propuestas-para-las-elecciones-europeas/
} 
gram). The five social movements analysed are the Assembly against Unconventional Gas Extraction in Cantabria, the Fracking EZ Araba Platform, the Andalusia Free from Fracking Platform, Comarques of Castelló Anti-Fracking Platform and the No Hydraulic Fracturing Assembly in Burgos. These platforms were the most active in their territories according to previous studies carried out by Álvarez, Castaños and Mercado (2015) in which they identified 16 platforms, associations or antifracking groups that maintained a differentiated identity on the web through different resources (site web, blog, Facebook profile or Twitter account). In relation to the NGOs, we have only taken into consideration the strategies that are focused on the issue of fracking.

All data were obtained from 2012 to 2015 because 2012 was the year of the fracking debate in Spain, the birth of the main anti-fracking groups and the origin of the first regional anti-fracking law passed in Cantabria. And until 2015 because is the implementation of the new Law 8/2015, dated May 21st, which modifies the Law 34/1998, dated October 7th, of the Hydrocarbons Sector, where hydraulic fracturing appears for the first time specified.

\subsection{Results}

The main strategy are aimed at the Administration, there are numerous reports and collected signatures presented in Government delegations and district councils. For example, the Comarques of Castelló Anti-Fracking Platform registered a report in the District council that alerted to the risks of fracking (June 27th 2014) ${ }^{5}$ and presented the Valencian courts with 50,000 signatures against the technique (February 25 th 2015) ${ }^{6}$. In the Basque Country, Fracking Ez Araba registered a Popular Legislative Initiative in the Basque parliament in $2013^{7}$.

The collection of signatures is a frequent action carried out by the ecologist organizations in general and also in relation to fracking, such as the over 3,000 signatures that were presented at the 2nd Potato Fair in Junta de Traslaloma (Las Merindades, Burgos, 10/05/2014) ${ }^{8}$ and others like the one carried out under the slo-

\footnotetext{
5 https://www.europapress.es/comunitat-valenciana/noticia-plataforma-anti-fracking-registradiputacion-informe-igme-avisa-riesgos-tecnica-20140627115154.html

${ }^{6}$ http://www.elmundo.es/comunidad-valenciana/2015/02/25/54edb0d2e2704ed5618b457e.html

7 https://www.elcorreo.com/vizcaya/v/20130201/alava/registran-iniciativa-popular-parlamento20130201.html

8 http://www.elcorreodeburgos.com/noticias/provincia/castrobarto-lucha-patata-3-600-firmasfracking_69332.html
} 
gan 'We are fed up'. Occasionally, the movements work together, such as when the Cantabria, Álava and Burgos platforms collected signatures in coordination with each other to make a claim against the "Angosto» permit, which affected an area of 26,100 hectares in the three provinces ${ }^{10}$. The signatures and the allegations were presented on February 19th 2015, in the Government Delegations ${ }^{11}$.

Following the press allows for the deduction of meetings and encounters with political representatives and participation in political activities. Ecologists in Action visited the Congress of Deputies in May 2013 on the invitation of the anti-fracking platforms. The representatives of the platforms came from Catalonia, Castellón, Teruel and Euskadi and they visited the Congress to explain the dangers of this extraction technique in the various territories ${ }^{12}$.

And also actions of supervision and judicial proceedings have been used, for example, by Verdemar-Ecologists in Action. On April 13th 2013 they presented an appeal against the resolution of the Ministry of Industry, Energy and Tourism that approved the permits for investigation of hydrocarbons through fracking for the companies Schuepbach Energy España and Vancast Exploration in parts of La Janda and Tarifa, in the province of Cádiz ${ }^{13}$. The NGO SEO/Birdlife supervises the requests for new shale gas projects in order to evaluate the potential impact on the environment.

Both the NGOs and the platforms work towards mobilization by offering informative talks or meetings ${ }^{14}$ and conferences that generate opinion. On its website, Ecologists in Action has eco-audios, videos that inform viewers about talks on fracking and access to the "Declaration of civil society against fracking and the Political commitment to prohibit hydraulic fracturing in the Spanish state», signed by various political parties. They edited the book "Global Resistance to Fracking» ${ }^{15}$ in the Books in Action collection that can be acquired online or downloaded for free. This

9 http://www.fracturahidraulicano.info/noticia/estamos-hartos-arranca-recogida-firmas-porextincion-permisos-fracking.html

10 http://www.fracturahidraulicano.info/permiso/angosto-1.html

11 https://elpais.com/ccaa/2015/02/18/paisvasco/1424265240_867187.html

12 https://www.europapress.es/sociedad/medio-ambiente-00647/noticia-ecologistas-explicanpsoe-iu-icv-bng-cha-rechazo-fracking-cita-asistencia-pp-ciu-upyd-pnv-20130522145531.html

13 https://www.europapress.es/sociedad/medio-ambiente-00647/noticia-ecologistas-pidenindustria-proyectos-fracking-andalucia-sometan-evaluacion-impacto-ambiental-20130413104920.html

14 http://www.fracturahidraulicano.info/galeria/campana-informativa-fracking-playas-cantabria.html

15 https://www.ecologistasenaccion.org/?p=30043 
NGO carries out cyber-actions for various topics, among which there is one that was directed towards the president of Castile-La Mancha at the time, Maria Dolores de Cospedal, in June 2013. 3,015 signatures were collected to show «the complete and utter rejection of the "Cronos» research permit for hydraulic fracturing that affects the province of Soria and Guadalajara» ${ }^{16}$. However, in the case of the platforms it is not frequent for there to be a request for economic contributions. Fracking Ez Araba offers t-shirts, bags and pens to support the cause for the organization of activities.

The convening of marches, demonstrations and concentrations is one of the most common actions of the movements. For example, on the website of the Assembly against Fracking in Burgos, we can find the stories of the various demonstrations, the majority of which are covered by Castilla y León TV with videos posted on YouTube ${ }^{17}$. On September 12th 2015, approximately 3,000 people demonstrated in the Burgos towns of Villarcayo Merindad de Castilla la Vieja and Medina de Pomar, to demand that the Council of Castilla y León create legislation in order to impede fracking, as has already occurred in various autonomous communities and countries in the world ${ }^{18}$. There have been anti-fracking carnivals, bicycle festivals and tractor protests. Fracking Ez Araba developed Frackanpada $2015^{19}$, an international protest camp against fracking that took place in Vitoria-Gasteiz from July 13 to 19th. Greenpeace and Ecologists in Action supported it on their websites ${ }^{20}$.

\footnotetext{
16 https://www.ecologistasenaccion.org/?p=33091

17 https://www.youtube.com/watch?v=gMtNpTQspc4

$18 \mathrm{http}: / /$ www.elcorreodeburgos.com/noticias/provincia/4-000-personas-claman-frackingmerindades_106516.html

19 http://www.fracturahidraulicano.info/noticia/acampada-contra-fracking-este-verano-vitoriagasteiz-frackanpada.html

${ }^{20}$ https://www.ecologistasenaccion.org/?p=29950
} 
TABle 2

Strategies and actions developed by environmental NGOs and anti-fracking platforms

\begin{tabular}{|c|c|c|c|c|c|c|c|c|c|c|c|c|}
\hline Target & Strategies & Actions & 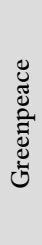 & 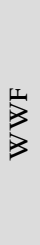 & 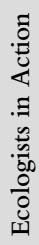 & 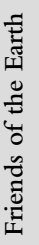 & 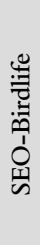 & 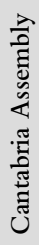 & 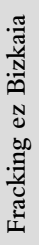 & 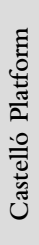 & 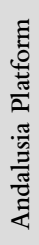 & 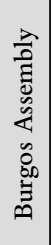 \\
\hline \multirow{4}{*}{$\begin{array}{l}\text { Public } \\
\text { Administration } \\
\text { (implications } \\
\text { and control) }\end{array}$} & $\begin{array}{l}\text { Institutional } \\
\text { Participation }\end{array}$ & $\begin{array}{l}\text { In commissions, advisory } \\
\text { councils, observatories }\end{array}$ & 0 & 0 & 1 & 0 & 0 & 1 & 1 & 1 & 1 & 1 \\
\hline & $\begin{array}{l}\text { Presentation } \\
\text { of institutional } \\
\text { documents }\end{array}$ & $\begin{array}{l}\text { Reports, requests } \\
\text { for information and } \\
\text { presentation of legislative } \\
\text { initiatives }\end{array}$ & 0 & 0 & 0 & 0 & 0 & 1 & 1 & 1 & 1 & 1 \\
\hline & $\begin{array}{l}\text { Encounters } \\
\text { and meetings }\end{array}$ & $\begin{array}{l}\text { Formal and informal } \\
\text { meetings, visits, forums }\end{array}$ & 1 & 1 & 1 & 1 & 1 & 1 & 1 & 1 & 1 & 1 \\
\hline & Supervision & $\begin{array}{l}\text { Lawsuits, complaints, } \\
\text { allegations for projects }\end{array}$ & 0 & 0 & 1 & 0 & 0 & 1 & 1 & 1 & 1 & 1 \\
\hline \multirow{5}{*}{$\begin{array}{c}\text { Citizens } \\
\text { (mobilization) }\end{array}$} & $\begin{array}{l}\text { Generation of } \\
\text { information } \\
\text { and opinion }\end{array}$ & $\begin{array}{l}\text { Manifestos, signature } \\
\text { collection, presence } \\
\text { on social medial, } \\
\text { cyber-actions }\end{array}$ & 1 & 1 & 1 & 1 & 1 & 1 & 1 & 1 & 1 & 1 \\
\hline & $\begin{array}{l}\text { Request for } \\
\text { economic } \\
\text { assistance }\end{array}$ & $\begin{array}{l}\text { Crowdfunding, } \\
\text { merchandising }\end{array}$ & 0 & 0 & 0 & 0 & 1 & 0 & 1 & 0 & 0 & 0 \\
\hline & $\begin{array}{l}\text { Organization } \\
\text { of events }\end{array}$ & $\begin{array}{l}\text { Seminars, exhibitions, } \\
\text { talks, fairs, courses, } \\
\text { festivals }\end{array}$ & 1 & 1 & 1 & 1 & 1 & 1 & 1 & 1 & 1 & 0 \\
\hline & Protest actions & $\begin{array}{l}\text { Demonstrations, } \\
\text { marches, escraches, } \\
\text { concentrations }\end{array}$ & 1 & 1 & 1 & 1 & 1 & 0 & 0 & 1 & 1 & 1 \\
\hline & $\begin{array}{l}\text { Confrontation } \\
\text { actions }\end{array}$ & $\begin{array}{l}\text { Aggressions, damage } \\
\text { to property, hacking, } \\
\text { occupations }\end{array}$ & 0 & 0 & 0 & 0 & 0 & 0 & 0 & 0 & 0 & ( \\
\hline $\begin{array}{c}\text { Media } \\
\text { (awareness, } \\
\text { visibility) }\end{array}$ & $\begin{array}{l}\text { Public } \\
\text { presentations }\end{array}$ & $\begin{array}{l}\text { Press conferences, } \\
\text { informative acts, } \\
\text { diffusion of studies, press } \\
\text { releases }\end{array}$ & 1 & 1 & 1 & 1 & 1 & 1 & 1 & 1 & 1 & 1 \\
\hline
\end{tabular}

Source: Own creation. 


\section{Discussion: effectiveness of the protest}

The most relevant difference between NGOs and anti-fracking platforms are the strategies aimed to public administration because they are really close to the local and regional governments. However, Ecologists in Action are the only NGO that has institutional participation, presented institutional documents, judicial actions and allegations and participated in encounters and meetings. This non-governmental organization has a federal structure, formed by local and regional groups, so it has very similar strategies as anti-fracking groups. Maybe here is the key of the effectiveness of the protest in the region where anti-fracking platforms have developed a bigger number of activities.

In this way, the Cantabria Assembly, with its actions, achieved an impact on political actions in the autonomous community that prohibited the technique in April $2013^{21}$. One month later, the Government of La Rioja approved its own law against fracking ${ }^{22}$ and in the same year, the regional government of Navarra, where Fracking Ez Nafarroa operates, followed suit ${ }^{23}$. These three laws were appealed by the State and declared void by the Constitutional Court (CC) in 2014 (in June for Cantabria, July for La Rioja and December for Navarra ${ }^{24}$. In the three cases, the CC concluded that the State has «exclusive competence to dictate the bases of the mining and energy regime». Despite the sentence by the CC, the approval of the law can be considered a success story for social mobilization coordinated through the anti-fracking assemblies and platforms.

In Andalusia, the spokesperson for environmental issues of the parliamentary group Izquierda Unida [United Left], Manuel Baena, defended in December 2014 a Draft Law presented by this group with the support of social organizations such as Ecologistas en Acción, Greenpeace and the Andalusia Free from Fracking Platform $^{25}$. The initiative of IU was not taken into consideration by the Parliament due to the negative vote from the PP [Popular Party] and the abstention of the PSOE [Socialist Workers' Party]. Finally, an extendible moratorium of two years was approved for these practices, on proposal of the $\mathrm{PSOE}^{26}$.

\footnotetext{
21 https://elpais.com/sociedad/2013/04/08/actualidad/1365443283_986703.html

${ }^{22}$ https://www.larioja.com/20130531/local/region/gobierno-rioja-prohibe-usar-201305311150.html

${ }^{23}$ https://www.boe.es/buscar/pdf/2013/BOE-A-2013-11695-consolidado.pdf

24 https://elpais.com/politica/2014/12/12/actualidad/1418391858_064103.html

25 https://www.ecologistasenaccion.org/?p=26631

${ }^{26}$ https://elpais.com/ccaa/2014/12/10/andalucia/1418239270_186773.html
} 
The Comarques de Castelló Anti-Fracking Platform met with the new Valencian Consell, which confirmed that in august 2015, fracking projects will not be authorized in Castellón ${ }^{27}$. It was then announced that from the month of September, the Consell will begin to process the law in order to prohibit the technique of hydraulic fracturing in the Community of Valencia.

Fracking Ez Araba registered a Popular Legislative Initiative (PLI) in the Basque parliament on January 31st 2013. The platform understood that, as well as maintaining and strengthening the campaigns for information, awareness and mobilization, the institutional method was also necessary, through the PLI, a formula that they understood to be «adequate in order to reflect the social rejection of fracking that exists in Basque society». The Bureau of Parliament due to negative votes from the PNV, PSE-EE and PP political parties did not accept this process. In December 2014, the PLI was eventually accepted in the Basque Parliament ${ }^{28}$. The debate was attended by various representatives of the platforms that are against the extraction of gas. Fracking Ez Araba received the support of 103,589 people, much higher than the 30,000 required to process a law of this type in the Parliament ${ }^{29}$. On June 20th 2015, the Basque Parliament approved the Law for additional environmental protection measures for the unconventional extraction of hydrocarbons and hydraulic fracturing or fracking, which, relying on the autonomic legislation for water, land and environment, impedes in practice that this technique can be used in Euskadi. The regulation was approved with the support of EH Bildu, PSE-EE and PP, while UPyD and PNV abstained. The parliament member of EH Bildu, Dani Maeztu, considers that this law is a "victory» of the "citizens' fight» and highlights that, with this new regulation, Basque competences are used to "close the door on fracking" and open a "public debate» on the energy strategy for Euskadi ${ }^{30}$.

On a national level, in May $14^{\text {th }}$ 2014, twenty-one anti-fracking platforms from different places of Spain and more than 40 social movements, where the five environmental NGOs analysed were included, reached in the Congress of Deputies a public and written agreement from 20 political parties ${ }^{31}$ to forbidding the hydraulic fracturing technic and stopping all the projects in progress if some of them would govern the country after the 2015 national election. All the political parties signed

\footnotetext{
27 https://elpais.com/ccaa/2015/08/06/valencia/1438874660_517274.html

${ }^{28} \mathrm{http}: / /$ www.fracturahidraulicano.info/noticia/admitida-a-tramite-iniciativa-legislativa-popularcontra-fracking-pais-vasco.html

${ }^{29} \mathrm{http}: / /$ www.fracturahidraulicano.info/noticia/103589-firmas-contra-fracking-pais-vasco.html

${ }^{30} \mathrm{https}$ ///www.europapress.es/euskadi/noticia-parlamento-vasco-aprueba-ley-evita-uso-frackingeuskadi-20150630113138.html

31 http://www.elmundo.es/comunidad-valenciana/2014/05/15/5374901b268e3efb348b4574.html
} 
the agreement except PP, PNV, UPyD and CIU. The "Agreement against hydraulic fracturing technic in Spain» made in "a worries by Spanish citizens because fracking projects were increasing all around the Spanish territory». Especially because Mario Rajoy Government had changed the two laws: 34/1998 Hydrocarbons Law and 12/2007, July 2sd Law, to improve a legal scenario and permission for the hydraulic fracturing technic projects and to look for the shale gas. The same day, in the afternoon, all the platforms and groups made a public activity to sign a document called «Social Civil Manifesto against fracking» with an environmental and social goal. In addition, they declared the relevance to bet for changing the power energy model to be more efficiency ${ }^{32}$.

The continuous social mobilization against fracking and other prospecting (oil in the Canary Islands and the Mediterranean) led to the modification of the Law of the Hydrocarbon Sector. As the newspaper El País stated when reporting about the law reformation project, this was carried out «to defeat the social opposition» $(12 / 12 / 2014)^{33}$. According to the newspaper, the Government wanted to defeat the opponents of fracking and of oil and gas prospecting «for the economic purposes», i.e., with new taxes for companies that would revert to the areas where the hydrocarbons will eventually be extracted. The communities, the Town Halls and the owners of the land would receive part of the money raised through these taxes, although only in the case that the companies do eventually launch the extraction projects. In article IV of the Law 8/2015, dated May 21st, which modifies the Law $34 / 1998$, dated October 7th, of the Hydrocarbons Sector, «the obligation for a social commitment with the local communities where said activities will be developed, which will allow for an adequate balance between the production of hydrocarbons and the necessities of these communities» is introduced.

On the other hand, StopFracking2015 campaign achieved that the political parties, except for PP, PNV, UPyD and $\mathrm{CIU}^{34}$, ratified their commitment to prohibit fracking. The initiative, consisting of over 200 social collectives ${ }^{35}$, has been promoted by 27 anti-fracking platforms. The sessions, held in Madrid on the 8th and 9th of September $2015^{36}$, included a experts roundtable, concentration in front of the Ministry of Agriculture, Food and Environment where the manifesto «Civil society against fracking» could be read and a meeting in the Congress of Deputies with the representatives of the political parties that signed the "Commitment for the pro-

\footnotetext{
32 https://www.ecologistasenaccion.org/SPIP/article27944.html?p=2018\&artpage =2-3

33 https://elpais.com/politica/2014/12/12/actualidad/1418384538_870154.html

34 https://elpais.com/politica/2015/09/09/actualidad/1441824591_837052.html

35 https://www.ecologistasenaccion.org/?p=30680

36 http://equomadrid.org/evento/iniciativa-stop-fracking-2015/
} 
hibition of hydraulic fracturing in the Spanish state». And the antifracking initiative was approved in the parliament in march $2016^{37}$.

In Spain, the Popular Party (PP) government passed a law in 2015 that facilitated the implementation of fracking projects in Spain, and corroborated the tendency in Europe to facilitate this type of industry in Europe, where the industry's lobbying action Commission Europe has been strong ${ }^{38}$. However, in Spain this open door has not meant the start-up of the project, thanks in part to the reaction of social movements and the support of regional governments through opposing legislation. Although the Constitutional Court has always knocked down these legislations, because it is a national competence. Despite this, the last resolutions of the Constitutional Court in 2018 on the antifracking law of the Basque Country, have only managed to annul parts of the legislation ${ }^{39}$, and the antifracking law of Castilla-La Mancha has passed the filter ${ }^{40}$, which is making it very difficult the start-up of these projects in Spain.

\section{Conclusions}

The anti-fracking protests are organized in Spain by two very different types of organization, the environmental NGOs and the social movements linked to the territory in the form of platforms or assemblies that are against the fracturing technique.

And could consider collective actors with a separate identity and strategic capability (Dolata \& Schrape, 2016). Their more important communication strategies are signatures collected, requests and social media presence. Scherman, Arriagada and Valenzuela (2013 \& 2016) have revealed a positive relationship between the use of social media (Facebook and Twitter) and participation in two massive protest movements-one against the construction of power plants in Chile.

Local environmental protest is more effectiveness than national environmental protest thanks to the grassroots and neighbourhood groups. Local social movements are easier organized and coordinated (Jiménez, 2005: 187). The different objectives

\footnotetext{
37 https://www.eldiario.es/sociedad/mayoria-Congreso-favor-fracturacion-hidraulica_0_ 499750537.html

38 https://corporateeurope.org/sites/default/files/attachments/carte_blanche_for_fracking_final.pdf

39 https://elpais.com/ccaa/2018/01/31/paisvasco/1517416694_253876.html

40 https://www.elconfidencial.com/tecnologia/ciencia/2018-06-21/fracking-castilla-la-manchaconstitucional_1581560/
} 
(broad vs. specific), structure and scope of action (national vs. regional or local) lead to an unbalanced intensity in the implementation of the communication and mobilization strategies. Nevertheless, NGOs work with local platforms in the objective to reach general agreements. Some achievements as «Agreement against hydraulic fracturing technic in Spain» (May, 2014) and StopFracking2015 campaign were successful thanks to the joint work of NGO and platform.

The particular specificity of the majority of environmental conflicts, very localized, called NIMBY (Not In My Back Yard), is relevant in the case of fracking. The social movements arise in areas where unconventional hydrocarbon exploration permits have been requested or authorized. However, the support, implication and collaboration of the environmental NGOs in this issue have provided the anti-fracking movement with greater visibility. As Jimenez (2005: 180) comments, «there are evidences that show different roles inside the environmental movements, both are complementary, between grassroots platforms activities and the lobby of the environmental NGOs».

Together, they have focused on the most recent initiatives such as Stop Fracking2015, through which they achieved the commitment of the opposition political parties to prohibit this technique in Spain if they reach government. All movements do not share this strategy, as some of them see this approach to politicians as a rejection of the principles of the assemblies and the citizens. Given the idea that the power of the people can change things, the majority seems to focus the objective on achieving the support of the parties that can create legislation. According to Thörn \& Svenberg (2016), the relationship between social movements and institutionalization can be understood with the concepts of (de) responsibility and (de) politicization in the context of new regulatory frameworks in environmental politics that has shaped interaction between social movements and the state in new ways, involving neoliberal responsibility, meaning active involvement by civil society in political responsibilities previously associated with state agencies.

This «national» tactic started after the Constitutional Court annulled the antifracking laws approved in Cantabria, La Rioja and Navarra, after they were appealed by the State with the Popular Party in power and the visible face of the Minister for Industry, José Manuel Soria, in favor of the technique. This is the motivation behind the synergies between platforms and political groups that are against the energy policy of the PP. If the PP loses the elections and another party moves into government, the social movements will have signed commitments for the prohibition of the technique that they will rely on. Even the Executive has been sensitive to the protests, modifying the Hydrocarbons Law in favor of the communities and the owners of the land. 
Therefore, the effectiveness of the social movements in the territories is significant, as has been shown by the approval of regional laws and the success of the Popular Legislative Initiative promoted by the Fracking Ez Araba Platform in the Basque Country. Local politicians rely on their anti-fracking voters, while state politicians have other interests, leading to an obvious clash in this issue between administrations, even within the same party. As it happens in other countries like US. Jaquith (2107) have examined whether local municipalities should have the capability to exercise their home rule authority to ban fracking within their jurisdiction, or whether state law should pretend such acts in US.

It is in the national and international scope where these movements start to gain traction to achieve the total prohibition of this technique, as stated by the most frequent slogan of the platforms: No to Fracking, not here not anywhere. Because the problem is global not only affect to Spain but also to other countries, that are developing into the single most important group of social and global environmental problems and of the first half of the twenty-first century (Van der Heijden, 2000).

Jimenez said in 2005 that environmental movement in Spain had improved its political effectiveness thank to develop anticipatory strategies and offer some political options. They had overtaken its reactive and negative reputations. After ten years, the success of the anti-fracking platforms will depend on the continuity of the protest and the capacity to convince the political parties of the sustainable energy alternatives that are being promoted in Europe. Their capacity to raise awareness and education in the public opinion will also depend on the transparency of their arguments and the information on the impact of fracking. The protest is associated to an entire communicative strategy that its effectiveness relies on, and in some cases, a lot of time has been required to achieve social and political change.

\section{References}

Álvarez, A., Castaños, A. \& Mercado, M.T. (2015). Plataformas antifracking y construcción mediática del riesgo. En C. Lozano (Ed.), La construcción del acontecer de riesgos y catástrofes. Cuadernos Artesanales 82 (pp. 105-118). La Laguna (Tenerife): Drago. Retrieved from http://www.cuadernosartesanos.org/2015/cac82.pdf

Anduiza, E., Cristancho, C. \& Sabucedo, J. M. (2014). Mobilization through online social networks: the political protest of the indignados in Spain. Information, Communication $\mathcal{E}$ Society, 17 (6), 750-764, DOI: http://10.1080/1369118X.2013.808360

Arroyo, I., Baladrón, A. \& Martín, R. (2013). La comunicación en redes sociales: percepciones y usos de las Ong españolas. Cuadernos.info, 32, 77-88. DOI: http://10.7764/ cdi.32.497 
Batill, K.M. \& Feldpausch-Parker, A. (2015). Hydrofracking in the news: how does media's coverage of hydraulic fracturing shape public discourse about emergying energy technologies in the U.S. En M. Meisner, N. Sriskandarajah \& S. Depoe (Eds.), Communication for the commons (pp. 176-190). Upsala: The International Environmental Communication Association.

Beloe, S. (2005). La ONG del siglo XXI. En el mercado, por el cambio. Zaragoza: Fundación Ecología y Desarrollo.

Briones, R., Kuch, B., Fisher, B. \& Jin, Y. (2011). Keeping up with the digital age: How the American Red Cross uses social media to build relationships. Public Relations Review, 37 (1), 37-43. DOI: http://10.1016/j.pubrev.2010.12.006

Brugué, Q., Font, J. \& Gomà, R. (2003). Participación y democracia. Asociaciones y poder local. In M.J. Funes \& R. Adell (eds.). Movimientos sociales: cambio social y participación (pp. 109-132) Madrid: UNED.

Berry, J.M. (1977). Lobbying for the people: The political behavior of public interest groups. Princeton: Princeton University Press.

Bortree, D.S., \& Seltzer, T. (2009). Dialogic strategies and outcomes: An analysis of environmental advocacy groups' Facebook profiles. Public Relations Review, 35, 317-319. DOI: http://10.1016/j.pubrev.2009.05.002

Buckingham, D. \& Rodríguez, C. (2013). Aprendiendo sobre el poder y la ciudadanía en un mundo virtual. Comunicar, 40, 49-58. DOI: http://dx.doi.org/10.3916/C40-2013-02-05

Burson Marsteller (2013). A guide to effective lobbying in Europe. The view of policy makers (http://goo.gl/mYyRht).

Castells, M. (2009). Comunicación y poder. Madrid: Alianza Editorial.

Castells, M. (2015). Redes de indignación y esperanza. Madrid: Alianza Editorial.

Centro de Investigaciones Sociológicas (2011). Postelectoral Elecciones General. Panel (2. ${ }^{a}$ fase). Estudio n. ${ }^{\circ}$ 2920. España.

Della Porta, D. (2011). Communication in movement. Information, Communication \& Society, 14(6), 800-819, DOI: http://10.1080/1369118X.2011.560954

Dolata, U. \& Schrape, J.F. (2016). Masses, Crowds, Communities, Movements: Collective Action in the Internet Age. Social Movement Studies, 15 (1), 1-18.

Edelman (2015). Edelman Trust Barometer. Annual Global Study. Retrieved from http://goo. $\mathrm{gl} / \mathrm{nCG} 7 \mathrm{oG})$.

Erro, J. (2002). Comunicación, desarrollo y ONGD. Bilbao: Hegoa.

Gabalín, C. (2014). Estudiantes conectados y movilizados: El uso de Facebook en las protestas estudiantiles en Chile. Comunicar, 43, 25-33. DOI http://dx.doi.org/10.3916/C43-2014-02

García, C., Fernández, C. y Del Olmo, J. (2018). La comunicación del Tercer Sector y el compromiso de los jóvenes en la era digital. Zer 23-44, pp. 155-174, doi.org/10.1387/zer.19164

Gerbaudo, P. (2012). Tweets and the streets: Social media and contemporary activism. London: Pluto Press.

Gomis, J. (2000). Ong, una nova manera de fer política. Lleida: Pagés editors. 
Greenberg, J., \& MacAulay, M. (2009). NPO 2.0? Exploring the web presence of environmental nonprofit organizations in Canada. Global Media Journal Canadian Edition, 2, 63-88.

Guo, Ch. \& Saxton, G. D. (2013). Tweeting Social Change: How Social Media Are Changing Nonprofit Advocacy. Nonprofit and Voluntary Sector Quartely, 43(1), 57-79. DOI:htt p://10.1177/0899764012471585

Herranz, J.M. (2011). Control, incidencia y comunicación de las organizaciones sociales sobre las políticas de las administraciones públicas. En C. Muñiz (coord.), Comunicación, política y ciudadanía (pp. 103-128). México D.F.: Fontamara.

Herranz, J.M. (2014). Different Ways to Reach Transparency and Trust through communication Management in Spanish Nonprofit Organizations. En J.A. Ariza-Montes \& A.M. Lucia-Casademunt (eds.), ICT Management in Non-Profit Organizations (pp. 36-55). Hershey: IGI Global.

Herranz, J.M., Sidorenko, P. \& Cantero, J.I. (2017). Rutinas comunicativas y lobbies en el sector medioambiental. En M. Mercado (ed.), El debate energético en los medios (pp. 127145). Barcelona: Editorial UOC.

Iranzo, A. \& Farné, A. (2014). Herramientas de comunicación para el tercer sector: El uso de las redes sociales por las ONGD Catalanas. Commons, Revista de comunicación y ciudadanía digital, 3 (2), 29-50.

Jaquith, K. (2017). The Tension Between State Interests and Municipal Zoning Rights in the Realm of Fracking Regulations. Environmental Claims Journal, 29, 49-65.

Jerez, A. \& Revilla, M. (1997). El tercer sector. Una revisión introductoria a un concepto polémico. En A. Jerez (ed.), ¿Trabajo voluntario o participación? Elementos para una sociología del Tercer Sector (pp. 26-45). Madrid: Tecnos.

Jiménez, M. (2005). El impacto político de los movimientos sociales. Un estudio de la protesta ambiental en España. Madrid: Siglo XXI.

Lovejoy, K. \& Saxton, G. D. (2012). Information, Community, and Action: How Nonprofit Organizations Use Social Media. Journal of Computer-Mediated Communication, 17, 337-353.

Mercado, M.T., Álvarez, À. \& Herranz, J.M. (2014). The fracking debate in the media: The role of citizen platforms as sources of information. ESSACHESS-Journal for Communication Studies, 7, 1(13), 45-62.

Monterde, A., Calleja-López, A. , Aguilera, M., Barandiaran, X. \& Postill, J. (2015). Multitudinous identities: a qualitative and network analysisof the $15 \mathrm{M}$ collective identity, Information, Communication \& Society, 18(8), 930-950. DOI: http://10.1080/1369118X.2015.104 3315

Nah, S., \& Saxton, G. D. (2013). Modeling the adoption and use of social media by nonprofit organizations. New Media \& Society, 15, 294-313. DOI: http://10.1177/146144 4812452411

Nos, E., Iranzo, A. \& Farné, A. (2012). La eficacia cultural de la comunicación de las ONGD: los discursos de los movimientos sociales actuales como revisión. CIC Cua- 
dernos de Información y Comunicación, 17, 209-237. DOI: http://dx.doi.org/10.5209/ rev_CIYC.2012.v17.39265

Nye, J. (2004). Soft power: the means to success in world politics. New York: Public Affairs.

Ramil, X. (2012). \#Paradigmátic@s. Comunicación y cultura digital en las ONG de Desarrollo. Madrid: Coordinadora de ONG para el Desarrollo-España.

Schwarz, A. \& Fritsch, A. (2014). Communicating on Behalf of Global Civil Society: Management and Coordination of Public Relations in International Nongovernmental Organizations. Journal of Public Relations Research, 26 (2), 161-183. DOI: http://10.1080/ 1062726X.2013.864242

Seo, H., Kim, J.Y., \& Yang, S.U. (2009). Global activism and new media: A study of transnational NGO's online public relations. Public Relations Review, 35, 123-126. DOI: http://10.1016/j.pubrev.2009.02.002

Scherman, A., Arriagada, A. \& Valenzuela, S. (2016). Student and environmental protests in Chile: The role of social media. Politics, 35 (2), 151-171.

Scherman, A., Arriagada, A. \& Valenzuela, S. (2013). La protesta en la era de las redes sociales: el caso chileno. Intermedios. Medios de comunicación y democracia en Chile, 1, 179197.

Tascón, M. y Quintana, Y. (2012). Ciberactivismo. Las nuevas revoluciones de las multitudes conectadas. Madrid: Los libros de la Catarata.

Torrella, F.J. (2014). Infraestructuras, industria y movimientos sociales. Estrategias de comunicación ante el proyecto de refinería Balboa en la provincia de Badajoz. Commons, Revista de comunicación y ciudadanía digital, 3 (2),112-136.

Toret, J., Calleja, A. et al. (2015). Tecnopolítica y 15M: La potencia de las multitudes conectadas. Barcelona: Editorial UOC.

Van der Heijden, H.A. (2010). Social Movements, Public Spheres and the European Politics of the Environment: Green Power Europe? Basingstoke: Palgrave Macmillan.

Velázquez, M.A. (2005). Relaciones entre organizaciones y movimientos sociales. Redes y oportunidades políticas: los casos de la Red Nacional de Acción Ecologista (Argentina) y la Red Nacional de Derecho a la Información ambiental (México). Región y Sociedad, XVII (33), 33-70.

Waters R.D., Burnett E., Lamm A., \& Lucas J. (2009). Engaging stakeholders through social networking: How nonprofit organizations are using Facebook. Public Relations Review, 35 (2), pp. 102-106. DOI: http://10.1016/j.pubrev.2009.01.006 